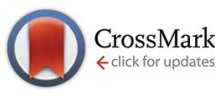

Cite this: Food Funct., 2015, 6, 2155

\title{
Bioactive formulations prepared from fruiting bodies and submerged culture mycelia of the Brazilian edible mushroom Pleurotus ostreatoroseus Singer
}

\author{
Rúbia Carvalho Gomes Corrêa, ${ }^{a, b, c}$ Aloisio Henrique Pereira de Souza, ${ }^{b, c}$ \\ Ricardo C. Calhelha, ${ }^{a}$ Lillian Barros, ${ }^{a}$ Jasmina Glamoclija, ${ }^{d}$ Marina Sokovic, ${ }^{d}$ \\ Rosane Marina Peralta, ${ }^{C}$ Adelar Bracht ${ }^{c}$ and Isabel C. F. R. Ferreira*a
}

\begin{abstract}
Pleurotus ostreatoroseus is a Brazilian edible mushroom whose chemical characterization and bioactivity still remain underexplored. In this study, the hydrophilic and lipophilic compounds as well as the antioxidant, anti-inflammatory and antimicrobial activities of formulations (ethanol extracts) prepared with its fruiting bodies and submerged culture mycelia were compared. The bioactive formulations contain at least five free sugars, four organic acids, four phenolic compounds and two tocopherols. The fruiting body-based formulation revealed higher reducing power, DPPH scavenging activity, $\beta$-carotene bleaching inhibition and lipid peroxidation inhibition in brain homogenates than the mycelium-based preparation, as well as higher anti-inflammatory and antimicrobial activities. The absence of hepatotoxicity was confirmed in porcine liver primary cells. These functional responses can be related to the levels of bioactive components including phenolic acids, organic acids and tocopherols.
\end{abstract}

Received 28th April 2015,
Accepted 30th May 2015
DOI: 10.1039/c5fo00465a
www.rsc.org/foodfunction

\section{Introduction}

Besides their worldwide-appreciated flavour, mushrooms offer exceptional nutritional value, with low lipid content and large amounts of carbohydrates and proteins, in addition to essential amino acids and fat-soluble vitamins (vitamins A, D, E and K). ${ }^{1}$ Moreover, mushrooms are increasingly attractive as functional foods and as potential sources for the development of new drugs. ${ }^{2}$

Among the bioactive compounds found in mushrooms, tocopherols, ${ }^{3}$ phenolic compounds ${ }^{4}$ and some organic acids ${ }^{5}$ have been implicated for their nutraceutical potential ${ }^{6,7}$ and bioactivity, including their antioxidant ${ }^{8,9}$ and antimicrobial ${ }^{10}$ effects.

Pleurotus is an important genus of basidiomycetes, especially; those occurring in the subtropics and tropics, which occupy the third position in the production of edible mush-

\footnotetext{
${ }^{a}$ Mountain Research Centre (CIMO), ESA, Polytechnic Institute of Bragança, Campus de Santa Apolónia, 1172, 5301-855 Bragança, Portugal. E-mail: iferreira@ipb.pt; Fax: +351-273-325405; Tel: +351-273-303219

${ }^{b}$ CAPES Foundation, Ministry of Education of Brazil, 70.040-020 Brasilia, DF, Brazil ${ }^{c}$ State University of Maringá, Department of Biochemistry, 87020-900 Maringá, PR, Brazil

${ }^{d}$ University of Belgrade, Department of Plant Physiology, Institute for Biological Research "Siniša Stanković", Bulevar Despota Stefana 142, 11000 Belgrade, Serbia
}

rooms. ${ }^{11,12}$ Pleurotus spp. can be easily cultivated due to their ability to colonise and degrade a wide variety of substrates containing cellulose, hemicellulose and lignin, using them in their own development. ${ }^{12,13}$ Furthermore, these species have a quick mycelium growth and fruiting, and a low cost of culture. $^{14,15}$ For these reasons, as well as their well-known nutritional and functional characteristics, Pleurotus spp. have become very interesting from a commercial point of view. ${ }^{12}$

Pleurotus ostreatoroseus Singer is an edible Brazilian mushroom that stands out for its characteristic rosy coloration and the delightful flavour of its fruiting bodies. It was firstly described by Singer ${ }^{16}$ from sample material collected at Dois Irmãos Park (Brazilian Atlantic Forest), Recife, PE, Brazil. This species is included among the white rot fungi for its excellent potential in lignin degradation and is considered an autochthonous mushroom in the tropics; it grows quite well in tropical temperatures. ${ }^{17}$

Although a few studies have covered the chemical characterization and antitumor and immunomodulatory effects of polysaccharides isolated from $P$. ostreatoroseus fruiting bodies, ${ }^{18-20}$ the chemical elucidation and bioactivity of other molecules, such as phenolic compounds, still remain unknown.

Regarding antioxidant, anti-inflammatory and antimicrobial effects of Pleurotus spp., there are some studies with Pleurotus ostreatus (Jacq. ex Fr.) P. Kumm, Pleurotus cystidiosus O.K. Mill, Pleurotus pulmonarius (Fr.) Quél, Pleurotus djamor 
(Rumph. ex Fr.), Pleurotus citrinopileatus Singer and Pleurotus eryngii (DC.) Quél. ${ }^{9,10,21-23}$ Nevertheless, to the authors' knowledge, there are no previous reports on antioxidant, anti-inflammatory and antimicrobial activities of $P$. ostreatoroseus.

In the present work, a study was performed with the fruiting body and mycelium of $P$. ostreatoroseus, by preparing bioactive formulations (ethanolic extracts) that were further characterized in terms of hydrophilic and lipophilic compounds. The antioxidant, anti-inflammatory and antimicrobial potential of the prepared extracts were evaluated and compared, and non-toxicity was confirmed in a primary cell culture of porcine liver cells.

\section{Experimental}

\section{Fruiting body selection and nutritional characterization}

Fruiting bodies (basidiocarps) of $P$. ostreatoroseus were obtained from a local producer in Maringá, PR, Brazil, in spring 2014. The fruiting bodies were selected in accordance with the commercial requirements in Brazil, i.e., before the rupture of the veil (closed cap), in order to preserve the sensory characteristics as well as firmness, which also reduces fragmentation during processing.

The fruiting bodies were nutritionally characterized regarding moisture, proteins, fat, carbohydrates and ash, by using the standard procedures. $^{24}$ The crude protein content $(\mathrm{N} \times$ 4.38) was estimated by the macro-Kjeldahl method; the crude fat was determined by extracting a known weight of powdered sample with petroleum ether, using a Soxhlet apparatus; the ash content was determined by incineration at $600 \pm 15{ }^{\circ} \mathrm{C}$. Total fibre was determined by enzymatic-gravimetric method. ${ }^{24}$ Carbohydrate value was calculated by difference.

\section{Production of the $P$. ostreatoroseus mycelia}

A commercial isolate of $P$. ostreatoroseus was obtained from a local producer. The stock culture was maintained on wheat bran extract agar slants (Fig. 1) and sub-cultured every month. The slants were incubated at $28{ }^{\circ} \mathrm{C}$ for 7 days and then stored at $4{ }^{\circ} \mathrm{C}$ in a refrigerator for up 30 days. The inocula were prepared by adding actively growing mycelia from a newly pre- pared slant culture (5 mycelial agar discs with $0.5 \mathrm{~cm}$ diameter) into $50 \mathrm{~mL}$ medium in a $250 \mathrm{~mL}$ Erlenmeyer flask. They were incubated for 5 days at $28{ }^{\circ} \mathrm{C}$ on a rotary shaker at $160 \mathrm{rpm}$. The wheat bran extract medium was prepared with $100 \mathrm{~g}$ of wheat bran that was boiled in $1 \mathrm{~L}$ of distilled water. The mixture was then filtered in gauze, and mineral solution ${ }^{25}$ at a final concentration of $2 \%$ was added to the filtrate. For the submerged culture, $150 \mathrm{~mL}$ of the same medium was prepared in a $500 \mathrm{~mL}$ flask, and pre-culture broth was inoculated (at $1.0 \mathrm{~mL} \mathrm{~L}^{-1}$ ). The flasks were incubated at $28{ }^{\circ} \mathrm{C}$ on a rotary shaker at $160 \mathrm{rpm}$ for up to 7 days. The mycelia were recovered from the liquid medium by filtration, washed with distilled water, immediately stored in the freezer and posteriorly freezedried.

\section{Preparation of the bioactive formulations}

The extraction procedure followed the methodology proposed by Carvajal et al. ${ }^{26}$ with ethanol chosen as the extractor solvent due to its low cost, abundance and lower toxicity in comparison with other organic solvents. Fruiting bodies were dried and milled to a fine powder (40 mesh) while the previously freeze-dried mycelia were milled to the same granulometry. The samples (5 g) were extracted by stirring with $100 \mathrm{~mL}$ of ethanol $70: 30$ (in water) at $25^{\circ} \mathrm{C}$ and at $130 \mathrm{rpm}$ for $3 \mathrm{~h}$ and filtered through Whatman no 1 paper. The extraction procedure was repeated twice. The combined filtrates were concentrated with a rotary vacuum evaporator at $40{ }^{\circ} \mathrm{C}$ in order to eliminate the solvent and posteriorly freeze-dry the formulation. The freeze-dried powders were stored in the freezer until use. The extraction yield was about $20 \%$ for both basidioma and mycelium samples.

\section{Standards and reagents}

Acetonitrile 99.9\%, $n$-hexane 95\% and ethyl acetate 99.8\% were of HPLC grade from Fisher Scientific (Lisbon, Portugal). Trolox (6-hydroxy-2,5,7,8-tetramethylchroman-2-carboxylic acid), sugar, organic acid and phenolic compound standards were from Sigma (St. Louis, MO, USA). Racemic tocol (50 mg $\mathrm{mL}^{-1}$ ) and tocopherols, were purchased from Matreya (PA, USA). 2,2-Diphenyl-1-picrylhydrazyl (DPPH) was obtained from Alfa Aesar (Ward Hill, MA, USA). Dimethylsulfoxide (DMSO)

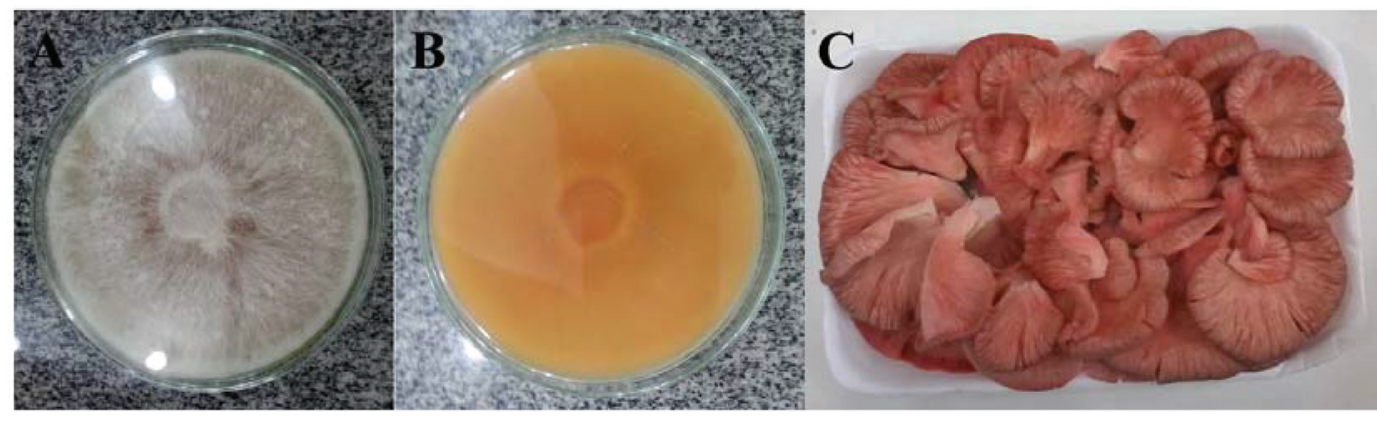

Fig. 1 Morphological characteristics of $P$. ostreatoroseus. (a) Mycelium cultivated on wheat bran extract agar slants. (b) Bottom of the mycelium plate of figure $a$ in which the characteristic rosy coloration can be observed. (c) Fruiting bodies of commercial package. 
(Merck KGaA, Germany) was used as a solvent in antimicrobial assays. Dulbecco's modified Eagle's medium, Hank's balanced salt solution (HBSS), fetal bovine serum (FBS), L-glutamine, trypsin-EDTA, penicillin/streptomycin solution $\left(100 \mathrm{U} \mathrm{mL} \mathrm{m}^{-1}\right.$ and $100 \mu \mathrm{g} \mathrm{mL} \mathrm{m}^{-1}$, respectively) were purchased from Gibco Invitrogen Life Technologies (California, USA). Sulforhodamine B, trypan blue, trichloroacetic acid (TCA) and Tris were purchased from Sigma Chemical Co. (Saint Louis, USA). RAW264.7 cells were purchased from ECACC ("European Collection of Animal Cell Culture”) (Salisbury, UK), lipopolysaccharide (LPS) from Sigma and DMEM medium from HyClone. The Griess Reagent System Kit was purchased from Promega, and dexamethasone from Sigma. Ethanol and all other chemicals were of analytical grade and purchased from common sources. Water was treated in a Milli-Q water purification system (TGI Pure Water Systems, Greenville, SC, USA).

\section{Chemical characterization of the $P$. ostreatoroseus formulations}

Free sugars. The extracts (500 mg) were spiked with the Internal Standard, IS (raffinose, $5 \mathrm{mg} \mathrm{mL}^{-1}$ ), re-dissolved in water $(5 \mathrm{~mL})$ and successively defatted three times with $10 \mathrm{~mL}$ of ethyl ether. After ethyl ether removal, the residues were filtered through a $0.22 \mu \mathrm{m}$ disposable LC filter disk and transferred into an injection vial. Analysis was performed by high performance liquid chromatography (HPLC). The total system consisted of an integrated system with a pump (Knauer, Smartline system1000, Berlin, Germany), degasser system (Smartline manager 5000) and an auto-sampler (AS-2057 Jasco, Easton, MD, USA), coupled to a refraction index detector (RI detector Knauer Smartline 2300), as previously described by the authors. ${ }^{27}$ The chromatographic separation was achieved with an Eurospher 100-5 $\mathrm{NH}_{2}$ column $(4.6 \mathrm{~mm} \times 250 \mathrm{~mm}, 5 \mu \mathrm{m}$, Knauer) operating at $35{ }^{\circ} \mathrm{C}(7971 \mathrm{R}$ Grace oven). The mobile phase used was acetonitrile/deionized water, $70: 30(\mathrm{v} / \mathrm{v})$ at a flow rate of $1 \mathrm{~mL} \mathrm{~min}^{-1}$. Sugar identification was made by comparing the relative retention times of sample peaks with standards. Data were analyzed using Clarity 2.4 Software (DataApex). Quantification was based on the RI signal response of each standard, using the internal standard (IS, raffinose) method and by using calibration curves obtained from the commercial standards of each compound. The results were expressed in $\mathrm{mg}$ per $\mathrm{g}$ of extract.

Organic acids. The extracts $(50 \mathrm{mg})$ were re-dissolved in meta-phosphoric acid (2 $\mathrm{mL})$ and subsequently filtered through Whatman no 4 paper. Organic acids were determined by ultra-fast liquid chromatography (UFLC, Shimadzu 20A series, Shimadzu Corporation, Kyoto, Japan) coupled with a photodiode array detector (PDA) as previously described by the authors. ${ }^{5}$ Separation was achieved on a Sphere Clone (Phenomenex) reverse phase $\mathrm{C}_{18}$ column $(5 \mu \mathrm{m}, 250 \mathrm{~mm} \times 4.6 \mathrm{~mm}$ i.d) thermostatted at $35{ }^{\circ} \mathrm{C}$. The elution was performed with $3.6 \mathrm{mM}$ sulphuric acid using a flow rate of $0.8 \mathrm{~mL} \mathrm{~min}^{-1}$. The organic acids were quantified by comparison of the area of their peaks recorded at $215 \mathrm{~nm}$ with calibration curves obtained from commercial standards of each compound. The results were expressed in mg per $\mathrm{g}$ of extract.

Phenolic acids. The extracts were re-dissolved in ethanol: water $(20: 80, \mathrm{v} / \mathrm{v})$ and filtered through a $0.22 \mu \mathrm{m}$ disposable LC filter disk for HPLC analysis. Phenolic acid determination was performed using the UFLC mentioned above, as previously described by Reis et $a .^{28}$ Separation was achieved with a Waters Spherisorb S3 ODS-2 $\mathrm{C}_{18}, 3 \mu \mathrm{m}(4.6 \mathrm{~mm} \times 150 \mathrm{~mm})$ column, thermostatted at $35{ }^{\circ} \mathrm{C}$. The solvents used were: (A) $0.1 \%$ formic acid in water, (B) acetonitrile. The elution gradient established was isocratic at $15 \% \mathrm{~B}$ for $5 \mathrm{~min}, 15 \% \mathrm{~B}$ to $20 \%$ B over $5 \mathrm{~min}, 20-25 \%$ B over $10 \mathrm{~min}, 25-35 \%$ B over $10 \mathrm{~min}, 35-50 \% \mathrm{~B}$ for $10 \mathrm{~min}$, and then re-equilibration of the column, using a flow rate of $0.5 \mathrm{~mL} \mathrm{~min}^{-1}$. Double online detection was carried out in the DAD using $280 \mathrm{~nm}$ as the preferred wavelength and in a mass spectrometer (MS) connected to a HPLC system via the DAD cell outlet. The phenolic compounds were characterized according to the UV and mass spectra, retention times, and comparison with authentic standards. The identified phenolic acids were quantified by comparison of the area of their peaks recorded at $280 \mathrm{~nm}$ with calibration curves obtained from commercial standards of each compound. The results were expressed in $\mu \mathrm{g}$ per $\mathrm{g}$ of extract.

Tocopherols. BHT solution $\left(10 \mathrm{mg} \mathrm{mL} \mathrm{m}^{-1}, 100 \mu \mathrm{L}\right)$ and IS solution (tocol $2 \mu \mathrm{g} \mathrm{mL} \mathrm{m}^{-1}, 250 \mu \mathrm{L}$ ) were added to the extracts (described above) prior to the extraction procedure. The extracts were homogenized with methanol $(4 \mathrm{~mL})$ by vortex mixing (1 min). Subsequently, hexane $(4 \mathrm{~mL})$ was added and the extracts were again vortex mixed for $1 \mathrm{~min}$. After that, a saturated $\mathrm{NaCl}$ aqueous solution $(2 \mathrm{~mL})$ was added, the mixture was homogenized ( $1 \mathrm{~min}$ ), centrifuged (5 min, 4000g) and the clear upper layer was carefully transferred to a vial. The sample was re-extracted twice with hexane. The combined extracts were taken to dryness under a nitrogen stream, re-dissolved in $1 \mathrm{~mL}$ of hexane, dehydrated with anhydrous sodium sulfate, filtered through a $0.22 \mu \mathrm{m}$ disposable LC filter disk, and transferred into a dark injection vial. Analysis was performed by HPLC (equipment described above), and a fluorescence detector (FP-2020; Jasco) programmed for excitation at $290 \mathrm{~nm}$ and emission at $330 \mathrm{~nm}$, as previously described by the authors. ${ }^{27}$ The chromatographic separation was achieved with a Polyamide II $(250 \times 4.6 \mathrm{~mm})$ normal-phase column from YMC Waters operating at $35{ }^{\circ} \mathrm{C}$. The mobile phase used was a mixture of hexane and ethyl acetate $(70: 30, \mathrm{v} / \mathrm{v})$ at a flow rate of $1 \mathrm{ml} \mathrm{min}^{-1}$. The compounds were identified by chromatographic comparisons with authentic standards. Quantification was based on the fluorescence signal response of each standard, using the IS (tocol) method and by using calibration curves obtained from commercial standards of each compound. The results were expressed in $\mu \mathrm{g}$ per $\mathrm{g}$ of extract.

\section{Bioactivity of the $\boldsymbol{P}$. ostreatoroseus formulations}

Antioxidant activity. Successive dilutions of the stock solution were made and used for in vitro assays as described by Reis et al., ${ }^{28}$ to evaluate the antioxidant activity of the samples. 
The sample concentrations $\left(\mathrm{mg} \mathrm{mL}^{-1}\right)$ providing $50 \%$ of antioxidant activity or 0.5 of absorbance $\left(\mathrm{EC}_{50}\right)$ were calculated from the graphs of antioxidant activity percentages (DPPH, $\beta$-carotene/linoleate and TBARS assays) or absorbance at $690 \mathrm{~nm}$ (ferricyanide/Prussian blue assay) against the sample concentrations. Trolox was used as a positive control.

Ferricyanide/prussian blue assay. The extract solutions with different concentrations $(0.5 \mathrm{~mL})$ were mixed with sodium phosphate buffer $\left(200 \mathrm{mmol} \mathrm{L}^{-1}, \mathrm{pH} 6.6,0.5 \mathrm{~mL}\right)$ and potassium ferricyanide $(1 \% \mathrm{w} / \mathrm{v}, 0.5 \mathrm{~mL})$. Each mixture was incubated at $50{ }^{\circ} \mathrm{C}$ for $20 \mathrm{~min}$, and trichloroacetic acid $(10 \% \mathrm{w} / \mathrm{v}, 0.5 \mathrm{~mL})$ was added. The mixture $(0.8 \mathrm{~mL})$ was poured into the 48 wells plate in addition to deionized water $(0.8 \mathrm{~mL})$ and ferric chloride $(0.1 \% \mathrm{w} / \mathrm{v}, 0.16 \mathrm{~mL})$, and the absorbance was measured at $690 \mathrm{~nm}$ in an ELX800 Microplate Reader (Bio-Tek Instruments, Inc.; Winooski, VT, USA).

$D P P H$ radical-scavenging activity assay. This methodology was performed using the Microplate Reader mentioned above. The reaction mixtures in the 96 well plate consisted of extract solutions of different concentrations $(30 \mu \mathrm{L})$ and a methanolic solution $(270 \mu \mathrm{L})$ containing DPPH radicals $\left(6 \times 10^{-5} \mathrm{~mol} \mathrm{~L}^{-1}\right)$. Each mixture was left to stand for $30 \mathrm{~min}$ in the dark, and the absorption was measured at $515 \mathrm{~nm}$. The radical scavenging activity (RSA) was calculated as a percentage of the DPPH discoloration using the equation: \%RSA $=\left[\left(A_{\mathrm{DPPH}}-A_{\mathrm{S}}\right) / A_{\mathrm{DPPH}}\right] \times$ 100 , where $A_{\mathrm{S}}$ is the absorbance of the solution containing the sample, and $A_{\mathrm{DPPH}}$ is the absorbance of the DPPH solution.

Inhibition of $\beta$-carotene bleaching or $\beta$-carotene/linoleate assay. A solution of $\beta$-carotene was prepared by dissolving $\beta$-carotene $(2 \mathrm{mg})$ in chloroform $(10 \mathrm{~mL})$. Two milliliters of this solution were pipetted into a round-bottom flask. The chloroform was removed at $40{ }^{\circ} \mathrm{C}$ under vacuum and linoleic acid (40 mg), Tween 80 emulsifier (400 mg), and distilled water $(100 \mathrm{~mL})$ were added to the flask with vigorous shaking. Aliquots $(4.8 \mathrm{~mL})$ of this emulsion were transferred into test tubes containing extract solutions at different concentrations $(0.2 \mathrm{~mL})$. The tubes were shaken and incubated at $50{ }^{\circ} \mathrm{C}$ in a water bath. As soon as the emulsion was added to each tube, the zero time absorbance was measured at $470 \mathrm{~nm}$. $\beta$-Carotene bleaching inhibition was calculated using the following equation: (Absorbance after $2 \mathrm{~h}$ of assay/initial absorbance) $\times 100$.

Thiobarbituric acid reactive substances (TBARS) assay. Porcine (Sus scrofa) brains were obtained from officially slaughtered animals, dissected, and homogenized with Polytron in an ice cold Tris- $\mathrm{HCl}$ buffer (20 mM, pH 7.4) to produce a $1: 2 \mathrm{w} / \mathrm{v}$ brain tissue homogenate which was centrifuged at $3000 \mathrm{~g}$ for $10 \mathrm{~min}$. An aliquot $(100 \mu \mathrm{L})$ of the supernatant was incubated with the different concentration sample solutions $(200 \mu \mathrm{L})$ in the presence of $\mathrm{FeSO}_{4}(10 \mathrm{mM} ; 100 \mu \mathrm{L})$ and ascorbic acid $(0.1 \mathrm{mM} ; 100 \mu \mathrm{L})$ at $37^{\circ} \mathrm{C}$ for $1 \mathrm{~h}$. The reaction was stopped by the addition of trichloroacetic acid $(28 \% \mathrm{w} / \mathrm{v}, 500 \mu \mathrm{L})$, followed by thiobarbituric acid (TBA, $2 \%, \mathrm{w} / \mathrm{v}, 380 \mu \mathrm{L}$ ), and the mixture was then heated at $80{ }^{\circ} \mathrm{C}$ for $20 \mathrm{~min}$. After centrifugation at $3000 \mathrm{~g}$ for $10 \mathrm{~min}$ to remove the precipitated protein, the color intensity of the malondialdehyde (MDA)-TBA complex in the supernatant was measured by its absorbance at $532 \mathrm{~nm}$. The inhibition ratio (\%) was calculated using the following formula: Inhibition ratio $(\%)=[(A-B) / A] \times 100 \%$, where $A$ and $B$ are the absorbances of the control and the sample solution, respectively.

Anti-inflammatory activity. The extracts were dissolved in water, initially concentrated at $8 \mathrm{mg} \mathrm{mL}^{-1}$ and then further dilutions were prepared from $8 \mathrm{mg} \mathrm{mL}^{-1}$ to $0.125 \mathrm{mg} \mathrm{mL} \mathrm{m}^{-1}$. The mouse macrophage-like cell line RAW264.7 was cultured in DMEM medium supplemented with $10 \%$ heat-inactivated fetal bovine serum and glutamine at $37{ }^{\circ} \mathrm{C}$ under $5 \% \mathrm{CO}_{2}$, in humidified air. For each experiment, cells were detached with a cell scraper. Under our experimental cell density $\left(5 \times 10^{5}\right.$ cells per $\mathrm{mL}$ ), the proportion of dead cells was less than $1 \%$, according to Trypan blue dye exclusion tests. Cells were seeded in 96-well plates at 150000 cells per well and allowed to attach to the plate overnight. Then, cells were treated with the different concentrations of each of the extracts for $1 \mathrm{~h}$. Dexamethasone $(50 \mu \mathrm{M})$ was used as a positive control for the experiment. The following step was stimulation with LPS $(1 \mu \mathrm{g}$ $\mathrm{mL}^{-1}$ ) for $18 \mathrm{~h}$. The effect of the tested samples in the absence of LPS was also evaluated, in order to observe if they induced changes in NO basal levels. In negative controls, no LPS was added. Both extracts and LPS were dissolved in supplemented DMEM. For the determination of nitric oxide, a Griess Reagent System kit (Promega) was used, which contains sulfanilamide, NED and nitrite solutions. One hundred microliters of each cell culture supernatant were transferred to the plate in duplicate and mixed with sulfanilamide and NED solutions, for 5-10 minutes each, at room temperature. The nitrite produced was determined by measuring the optical density at $515 \mathrm{~nm}$, in the microplate reader referred to above, and was compared to the standard calibration curve.

Antibacterial activity. The following Gram-negative bacteria: Escherichia coli (ATCC 35210), Pseudomonas aeruginosa (ATCC 27853), Salmonella typhimurium (ATCC 13311), Enterobacter cloacae (ATCC 35030), and Gram-positive bacteria: Staphylococcus aureus (ATCC 6538), Bacillus cereus (clinical isolate), Micrococcus flavus (ATCC 10240), and Listeria monocytogenes (NCTC 7973) were used. The microorganisms were obtained from the Mycological laboratory, Department of Plant Physiology, Institute for biological research "Siniša Stanković", University of Belgrade, Serbia.

The minimum inhibitory (MIC) and minimum bactericidal (MBC) concentrations were determined by the microdilution method. ${ }^{29}$ Each fresh overnight culture of bacteria was adjusted spectrophotometrically to a concentration of $1 \times 10^{5}$ CFU $\mathrm{mL}^{-1}$. The requested CFU $\mathrm{mL}^{-1}$ corresponded to a bacterial suspension determined in a spectrophotometer at $625 \mathrm{~nm}$ (OD625). Dilutions of inocula were cultured on solid medium to verify the absence of contamination and check the validity of each inoculum. Different solvent dilutions of the ethanolic extract were added to the wells containing $100 \mu \mathrm{L}$ of Tryptic Soy Broth (TSB) and afterwards, $10 \mu \mathrm{L}$ of inoculum was added to all wells. The microplates were incubated for $24 \mathrm{~h}$ at $37{ }^{\circ} \mathrm{C}$. The MIC of the samples was detected following the addition of $40 \mu \mathrm{L}$ of iodonitrotetrazolium chloride (INT) 
$\left(0.2 \mathrm{mg} \mathrm{mL} \mathrm{m}^{-1}\right)$ and incubation at $37{ }^{\circ} \mathrm{C}$ for $30 \mathrm{~min}$. The lowest concentration that produced a significant inhibition (around $50 \%$ ) of the growth of the bacteria in comparison with the positive control was identified as the MIC. The minimum inhibitory concentrations (MICs) obtained from the susceptibility testing of various bacteria to tested extracts were determined also by a colorimetric microbial viability assay based on the reduction of the INT color and compared with a positive control for each bacterial strain. ${ }^{30}$ MBC was determined by serial sub-cultivation of $10 \mu \mathrm{L}$ into microplates containing $100 \mu \mathrm{L}$ of TSB. The lowest concentration that showed no growth after this sub-culturing was read as the MBC. Standard drugs, namely streptomycin and ampicillin, were used as positive controls. 5\% DMSO was used as the negative control. Samples were tested in duplicate and experiments were repeated three times.

Antifungal activity. For the antifungal bioassays, the following microfungi were used: Aspergillus fumigatus (ATCC 1022), Aspergillus versicolor (ATCC 11730), Aspergillus ochraceus (ATCC 12066), Aspergillus niger (ATCC 6275), Trichoderma viride (IAM 5061), Penicillium funiculosum (ATCC 36839), Penicillium ochrochloron (ATCC 9112), and Penicillium verrucosum var. cyclopium (food isolate). The organisms were obtained from the Mycological Laboratory, Department of Plant Physiology, Institute for Biological Research "Siniša Stanković, Belgrade, Serbia. The micromycetes were maintained on malt agar (MA) and the cultures were stored at $4{ }^{\circ} \mathrm{C}$ and sub-cultured once a month. ${ }^{31}$

The fungal spores were washed from the surface of agar plates with sterile $0.85 \%$ saline containing $0.1 \%$ Tween 80 $(\mathrm{v} / \mathrm{v})$. The spore suspension was adjusted with sterile saline to a concentration of approximately $1.0 \times 10^{5}$ in a final volume of $100 \mu \mathrm{L}$ per well. The inocula were stored at $4{ }^{\circ} \mathrm{C}$ for further use. Dilutions of each inoculum were cultured on solid MA to verify the absence of contamination and to check the validity of the inoculum.

Minimum inhibitory concentration (MIC) determination was performed by a serial dilution technique using 96-well microtitre plates. The investigated extract was dissolved in a $5 \%$ solution of DMSO and added to broth malt medium with a fungal inoculum. The microplates were incubated for $72 \mathrm{~h}$ at $28{ }^{\circ} \mathrm{C}$. The lowest concentrations without visible growth (as assessed using a binocular microscope) were defined as the MICs. The minimum fungicidal concentrations (MFCs) were determined by serial sub-cultivation of $2 \mu \mathrm{L}$ in microtitre plates containing $100 \mu \mathrm{L}$ of malt broth per well and further incubation for $72 \mathrm{~h}$ at $28{ }^{\circ} \mathrm{C}$. The lowest concentration with no visible growth was defined as the MFC, indicating 99.5\% killing of the original inoculum. 5\% DMSO was used as a negative control, while bifonazole and ketoconazole were used as positive controls. Samples were tested in duplicate and experiments were repeated three times.

Toxicity for liver cells. A cell culture was prepared from a freshly harvested porcine liver obtained from a local slaughter house. It was designated as PLP2. Briefly, the liver tissues were rinsed in Hank's balanced salt solution containing $100 \mathrm{U}$ $\mathrm{mL}^{-1}$ penicillin and $100 \mu \mathrm{g} \mathrm{mL}^{-1}$ streptomycin, and divided

into $1 \times 1 \mathrm{~mm}^{3}$ explants. Some of these explants were placed in $25 \mathrm{~cm}^{3}$ tissue flasks in DMEM supplemented with $10 \%$ fetal bovine serum, $2 \mathrm{mM}$ nonessential amino acids, $100 \mathrm{U} \mathrm{mL}^{-1}$ penicillin and $100 \mu \mathrm{g} \mathrm{mL} \mathrm{m}^{-1}$ streptomycin, and incubated at $37{ }^{\circ} \mathrm{C}$ with a humidified atmosphere containing $5 \% \mathrm{CO}_{2}$. The medium was changed every 2 days. Cultivation of the cells was continued with direct monitoring every 2-3 days using a phase contrast microscope. Before confluence, cells were sub-cultured and plated in 96-well plates at a density of $1.0 \times 10^{4}$ cells per well, and cultivated in DMEM medium with 10\% FBS, 100 $\mathrm{U} \mathrm{mL}^{-1}$ penicillin and $100 \mu \mathrm{g} \mathrm{mL}{ }^{-1}$ streptomycin. ${ }^{32}$ Cells were treated for $48 \mathrm{~h}$ with the different diluted sample solutions and the same procedure described in the previous section for the SRB assay was followed. The results were expressed as $\mathrm{GI}_{50}$ values (sample concentrations that inhibited $50 \%$ of the net cell growth). Ellipticine was used as a positive control.

\section{Statistical analysis}

Three samples were used and all the assays were carried out in triplicate. The results are expressed as mean values with standard deviations (SD). Results were compared by means of a Student's $t$-test to determine the significant difference among samples, with $p \leq 0.05$. The analysis was carried out using the SPSS v. 22.0 program (IBM Corp., Armonk, NY, USA).

\section{Results and discussion}

\section{Chemical characterization of the P. ostreatoroseus formulations}

The P. ostreatoroseus fruiting body was nutritionally characterized and the results are presented in Table 1 . The sample showed regular contents of moisture and ash, besides an exceptional content of total fibre. The basidioma also presented a high content of protein and low fat levels. Patil et al. ${ }^{33}$ reported a similar value of protein content $(21 \mathrm{~g} / 100 \mathrm{~g})$ for Pleurotus ostreatus. Fernandes et al. ${ }^{12}$ found very distinct nutritional values referring to protein and carbohydrate contents for $P$. ostreatus, but similar results referring to moisture and ash contents.

The herein characterized fruiting bodies and the mycelia produced by submerged culture were subjected to an ethanolic extraction in order to prepare bioactive formulations, which were characterized in terms of hydrophilic and lipophilic compounds (Table 2). Regarding the free sugar composition, it was

Table 1 Nutritional characterization of $P$. ostreatoroseus fruiting bodies expressed on a dry weight basis (mean \pm SD)

P. ostreatoroseus fruiting bodies

Fat $(\mathrm{g} / 100 \mathrm{~g})$

Proteins $(\mathrm{g} / 100 \mathrm{~g})$

Ash $(\mathrm{g} / 100 \mathrm{~g})$

Carbohydrates $(\mathrm{g} / 100 \mathrm{~g})$

Total fibre $(\mathrm{g} / 100 \mathrm{~g})$
$3.0 \pm 0.1$

$26.0 \pm 0.2$

$7.6 \pm 0.1$

$18.4 \pm 0.1$

$45.0 \pm 0.2$ 
Table 2 Chemical characterization of $P$. ostreatoroseus fruiting bodyand mycelium-based formulations (mean \pm SD)

\begin{tabular}{|c|c|c|c|}
\hline Free sugars & $\begin{array}{l}\text { Fruiting } \\
\text { body }\end{array}$ & Mycelium & $\begin{array}{l}t \text {-Students } \\
\text { test } p \text {-value }\end{array}$ \\
\hline Fructose & $0.46 \pm 0.05$ & $10 \pm 1$ & $<0.001$ \\
\hline Mannitol & $12.0 \pm 0.1$ & $15 \pm 1$ & 0.006 \\
\hline Sucrose & $0.84 \pm 0.09$ & $10 \pm 1$ & $<0.001$ \\
\hline Trehalose & $10.3 \pm 0.5$ & $15.6 \pm 0.3$ & $<0.001$ \\
\hline Melezitose & $2.44 \pm 0.03$ & $7.5 \pm 0.4$ & $<0.001$ \\
\hline Total (mg g ${ }^{-1}$ extract) & $26.0 \pm 0.3$ & $58 \pm 3$ & $<0.001$ \\
\hline \multicolumn{4}{|l|}{ Organic acids } \\
\hline Oxalic acid & $12 \pm 1$ & $39 \pm 6$ & $<0.001$ \\
\hline Malic acid & $95 \pm 1$ & $52 \pm 1$ & $<0.001$ \\
\hline Citric acid & $101 \pm 26$ & $0.063 \pm 0.002$ & $<0.001$ \\
\hline Fumaric acid & $4.14 \pm 0.01$ & $\mathrm{nd}^{a}$ & - \\
\hline Total (mg g ${ }^{-1}$ extract) & $212 \pm 25$ & $91 \pm 8$ & $<0.001$ \\
\hline \multicolumn{4}{|l|}{ Phenolic compounds } \\
\hline$p$-Hydroxybenzoic acid & $0.129 \pm 0.001$ & nd & - \\
\hline cis $p$-Coumaric acid & $0.03 \pm 0.01$ & nd & - \\
\hline trans $p$-Coumaric acid & $0.032 \pm 0.003$ & nd & - \\
\hline Cinnamic acid & $0.050 \pm 0.002$ & $0.0065 \pm 0.0005$ & $<0.001$ \\
\hline Total ( $\mu \mathrm{g} \mathrm{g}^{-1}$ extract) & $0.24 \pm 0.01$ & $0.0065 \pm 0.0005$ & $<0.001$ \\
\hline \multicolumn{4}{|l|}{ Tocopherols } \\
\hline$\alpha$-Tocopherol & $0.08 \pm 0.00$ & $0.09 \pm 0.01$ & 0.083 \\
\hline$\beta$-Tocopherol & $0.45 \pm 0.02$ & $0.41 \pm 0.01$ & 0.026 \\
\hline Total $\left(\mu \mathrm{g} \mathrm{g}^{-1}\right.$ extract $)$ & $0.53 \pm 0.02$ & $0.50 \pm 0.01$ & 0.044 \\
\hline
\end{tabular}

possible to quantify five distinct compounds, namely fructose, mannitol, sucrose, trehalose, and melezitose (Fig. 2). The mycelium-based formulation revealed higher contents of all identified sugars than the basidioma-based preparation, with a total content of free sugars more than 2-fold higher. This notable difference between the total sugar content presented by the studied formulations could be explained, among other reasons, by the utilization of a sugar-rich wheat bran extract medium to produce the mycelium biomass. Once it is impossible to eliminate all the sugar provided by the culture medium through the filtration and washing processes previously described, the mycelium sample might have assimilated some free sugars from the medium. Reis et al. ${ }^{27}$ reported lower contents of fructose $\left(0.1 \pm 0.00 \mathrm{mg} \mathrm{g}^{-1}\right.$ extract and $0.3 \pm 0.00 \mathrm{mg}$ $\mathrm{g}^{-1}$ extract) and mannitol $\left(5.4 \pm 0.04 \mathrm{mg} \mathrm{g}^{-1}\right.$ extract and $6.0 \pm$ $0.00 \mathrm{mg} \mathrm{g}^{-1}$ extract) for ethanolic extracts of Pleurotus ostreatus and Pleurotus eryngii, respectively. These authors also found a lower content of sucrose $\left(0.3 \pm 0.00 \mathrm{mg} \mathrm{g}^{-1}\right.$ extract $)$ in the ethanolic extract of $P$. eryngii. Beluhan and Ranogajec ${ }^{34}$ reported a much higher content of mannitol $\left(98.20 \pm 0.55 \mathrm{mg} \mathrm{g}^{-1}\right.$ extract) and a similar content of trehalose $\left(17.9 \pm 0.12 \mathrm{mg} \mathrm{g}^{-1}\right.$ extract) for an ethanolic extract prepared from basidiomas of P. ostreatus.

It was possible to quantify four different organic acids (Table 2), namely oxalic, malic, citric and fumaric acids. The mycelium-based formulation revealed the highest concentration of oxalic acid, while the fruiting body-based formulation presented the highest contents of malic and citric acids. Fumaric acid was only found in the fruiting body extract, which also presented the highest content of total organic acids. The profile of organic acids described by Fernandes et $a .^{12}$ for $P$. ostreatus was slightly different, since the authors detected quinic instead of malic acid.

The prepared formulations revealed the presence of $p$-hydroxybenzoic, cis $p$-coumaric and trans $p$-coumaric acids, as well as cinnamic acid (Table 2). $p$-Hydroxybenzoic, cis $p$-coumaric and trans $p$-coumaric acids were only found in the fruiting body-based formulation. Cinnamic acid was found in both formulations, although the fruiting body extract had much the higher content of this compound. The fruiting body-based formulation was clearly richer in phenolic acids compared with the mycelium-based one. Reis et $a{ }^{28}{ }^{28}$ also reported the presence of $p$-hydroxybenzoic in the basidioma and mycelium of

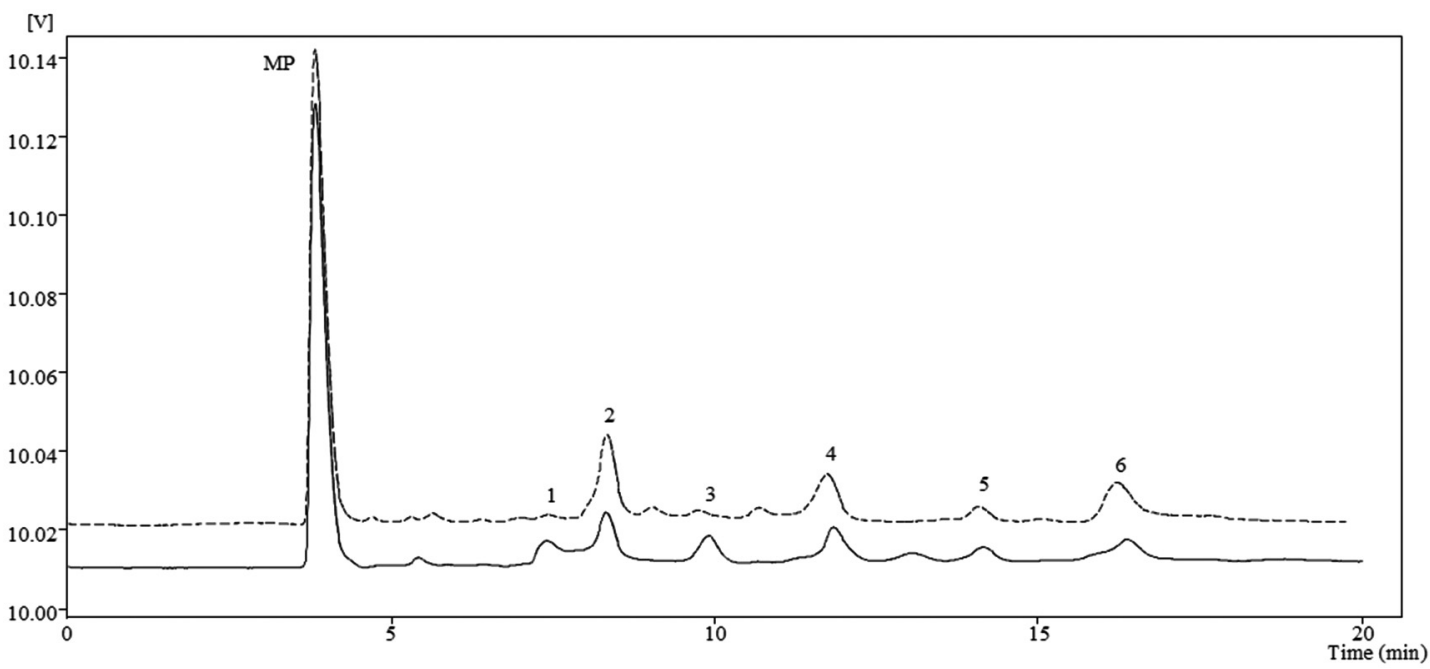

Fig. 2 Individual profiles of $P$. ostreatoroseus fruiting body (--) and mycelium (-) with regard to sugars: 1 - fructose, 2 - mannitol, $3-$ sucrose, 4 - trehalose, 5 - melezitose, 6 - raffinose (IS) and MP - mobile phase. 
P. ostreatus $\left(1.56 \pm 0.06\right.$ and $0.05 \pm 0.00 \mathrm{l} \mu \mathrm{g} \mathrm{g}^{-1} \mathrm{dw}$, respectively), as well as cinnamic acid $(0.23 \pm 0.02$ and $9.65 \pm 0.86 \mu \mathrm{g}$ $\mathrm{g}^{-1} \mathrm{dw}$, respectively).

$\alpha$-Tocopherol and $\beta$-tocopherol were found in both formulations, with no statistical differences in the contents of each of these compounds. These two vitamers of tocopherols were also present in the profile of Pleurotus species reported by Reis et $a l .{ }^{27}$ and Lin et $a l .{ }^{21}$

\section{Bioactivity of the $P$. ostreatoroseus formulations}

The fruiting body-based formulation revealed higher reducing power, DPPH scavenging activity, $\beta$-carotene bleaching inhibition and lipid peroxidation inhibition in brain homogenates than the mycelium-based preparation (Table 3). Reis et al. ${ }^{28}$ reported lower reducing power $\left(\mathrm{EC}_{50}\right.$ values $=3.31 \pm 0.03 \mathrm{mg}$ $\mathrm{mL}^{-1}$ and $3.72 \pm 0.09 \mathrm{mg} \mathrm{ml}^{-1}$, respectively), DPPH scavenging activity $\left(6.54 \pm 0.16 \mathrm{mg} \mathrm{mL} L^{-1}\right.$ and $8.67 \pm 0.12 \mathrm{mg} \mathrm{mL}^{-1}$, respectively), $\beta$-carotene bleaching inhibition $\left(\mathrm{EC}_{50}\right.$ values $=$ $2.74 \pm 0.16 \mathrm{mg} \mathrm{mL} \mathrm{m}^{-1}$ and $4.68 \pm 0.60 \mathrm{mg} \mathrm{mL}^{-1}$, respectively) and TBARS formation inhibition $\left(\mathrm{EC}_{50}\right.$ values $2.58 \pm 0.86 \mathrm{mg}$ $\mathrm{mL}^{-1}$ and $3.95 \pm 0.58 \mathrm{mg} \mathrm{mL} \mathrm{m}^{-1}$, respectively) for methanolic extracts prepared from basidiomas of $P$. ostreatus and P. eryngii. Regarding the DPPH scavenging activity, Tsai et al. ${ }^{35}$ reported lower activity in ethanolic extracts of $P$. ostreatus from Taiwan $\left(5.58 \pm 0.24 \mathrm{mg} \mathrm{mL}^{-1}\right)$. Also, the $P$. ostreatoroseus mycelium ethanolic extract studied herein had higher DPPH scavenging activity than the $P$. ostreatus and $P$. eryngii mycelia methanolic extracts $\left(\mathrm{EC}_{50}\right.$ values $58.13 \pm 3.02 \mathrm{mg} \mathrm{mL} \mathrm{m}^{-1}$ and $25.40 \pm 0.33 \mathrm{mg} \mathrm{mL}{ }^{-1}$, respectively ${ }^{28}$ ). The studied ethanolic preparation revealed lower lipid peroxidation inhibition measured by the TBARS assay than the mycelium methanolic extract of $P$. ostreatus $\left(\mathrm{EC}_{50}\right.$ value $\left.=1.08 \pm 0.86 \mathrm{mg} \mathrm{mL} \mathrm{m}^{-1}\right)$,

Table 3 Bioactivity of $P$. ostreatoroseus fruiting body- and myceliumbased formulations $(\text { mean } \pm \mathrm{SD})^{a}$

\begin{tabular}{|c|c|c|c|}
\hline & $\begin{array}{l}\text { Fruiting } \\
\text { body }\end{array}$ & Mycelium & $\begin{array}{l}t \text {-Students } \\
\text { test } p \text {-value }\end{array}$ \\
\hline \multicolumn{4}{|c|}{ Antioxidant activity $\left(\mathrm{EC}_{50}\right.$ values, $\left.\mathrm{mg} \mathrm{mL}^{-1}\right)$} \\
\hline Reducing power & $1.79 \pm 0.01$ & nd & - \\
\hline DPPH scavenging act & $4.78 \pm$ & $15.62 \pm 0.13$ & $<0.001$ \\
\hline $\begin{array}{l}\text { p-carotene Deacning } \\
\text { inhibition }\end{array}$ & 0.40 & & \\
\hline TBARS inhibition & $0.29 \pm 0.00$ & $2.34 \pm 0.08$ & $<0.001$ \\
\hline \multicolumn{4}{|c|}{ Anti-inflammatory activity $\left(\mathrm{EC}_{50}\right.$ values, $\left.\mu \mathrm{g} \mathrm{mL}^{-1}\right)$} \\
\hline NO production & $229.75 \pm 4.25$ & 261.2 & 0.011 \\
\hline \multicolumn{4}{|c|}{ Hepatotoxicity $\left(\mathrm{GI}_{50}\right.$ values, $\mu \mathrm{g} \mathrm{m \textrm {L } ^ { - 1 } )}$} \\
\hline PLP2 growth inhibition & $>400$ & $>400$ & - \\
\hline \multicolumn{4}{|c|}{$\begin{array}{l}{ }^{a} \text { Results of antioxidant activity are expressed as } \mathrm{EC}_{50} \text { values: sample } \\
\text { concentration providing } 50 \% \text { of antioxidant activity or } 0.5 \text { of absorbance } \\
\text { in the reducing power assay. Trolox EC }{ }_{50} \text { values: } 41 \mu \mathrm{g} \mathrm{mL}^{-1} \text { (reducing } \\
\text { power), } 42 \mu \mathrm{g} \mathrm{mL}^{-1} \text { (DPPH scavenging activity), } 18 \mu \mathrm{g} \mathrm{mL}^{-1} \text { ( }(\beta \text {-carotene } \\
\text { bleaching inhibition) and } 23 \mu \mathrm{g} \mathrm{mL} \mathrm{m}^{-1} \text { (TBARS inhibition). Results of } \\
\text { anti-inflammatory activity are expressed as } \mathrm{EC}_{50} \text { values: sample } \\
\text { concentration providing } 50 \% \text { inhibition in the production of NO. } \\
\text { Dexamethasone } \mathrm{EC}_{50} \text { value is } 16 \mu \mathrm{g} \mathrm{mL}^{-1} \text {. Results of hepatotoxicity are } \\
\text { expressed as GI } \mathrm{GI}_{50} \text { values: sample concentration providing } 50 \% \\
\text { inhibition of the net cell growth. Ellipticine } \mathrm{GI}_{50} \text { value is } 2.3 \mu \mathrm{g} \mathrm{mL} \mathrm{mL}^{-1} \text {. }\end{array}$} \\
\hline
\end{tabular}

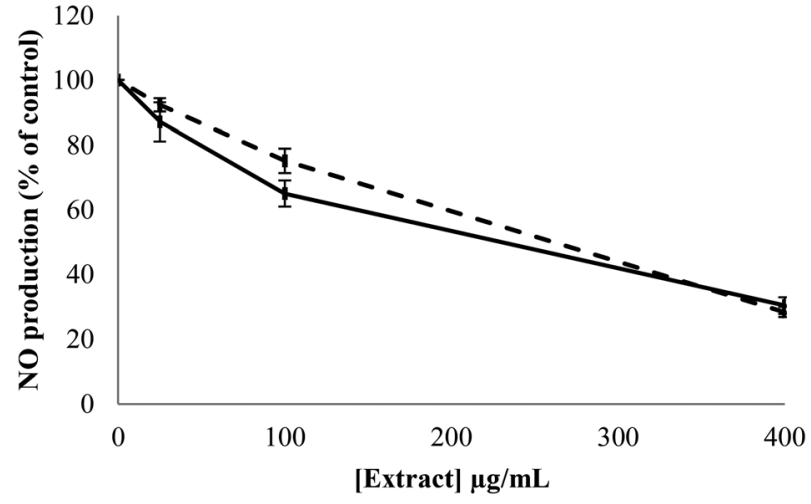

Fig. 3 Nitric oxide production as a function of concentration of $P$. ostreatoroseus fruiting body- (-) and mycelium- (--) based formulations. As the production of nitric oxide is proportional to the inflammatory process, a decrease in the nitric oxide concentration corresponds to potential anti-inflammatory activity.

but a much higher inhibition than the mycelium extract of. P. eryngii $\left(\mathrm{EC}_{50}\right.$ value $\left.=21.03 \pm 0.45 \mathrm{mg} \mathrm{mL}^{-1}\right)$, as reported by Reis et al. ${ }^{28}$

$P$. ostreatoroseus formulations revealed a dose-dependent potential anti-inflammatory activity (Fig. 3), with a relevant decrease of NO production even in the presence of lower concentration extracts (up to $400 \mu \mathrm{g} \mathrm{mL} \mathrm{m}^{-1}$ ). The fruiting bodybased formulation revealed higher activity (lower $\mathrm{EC}_{50}$ value) than the mycelium-based preparation (Table 3). Moro et al. ${ }^{36}$ investigated the anti-inflammatory activity of a methanolic extract of $P$. ostreatus in LPS-activated macrophages and reported no anti-inflammatory activity. Nonetheless, Lin et $a l .^{21}$ reported anti-inflammatory effects of ethanolic extracts from $P$. eryngii fruiting bodies and correlated these effects with their contents of antioxidant components. Thus, the higher anti-inflammatory activity revealed by the fruiting body-based formulation, when compared to the correspondent myceliumbased preparation, may be justified by its higher contents of hydrophilic and lipophilic antioxidant compounds, including phenolic acids, as also due to its higher antioxidant capacity. In fact, oxidative stress caused by the production of nitric oxide (NO) during inflammation processes has been related to the occurrence of several diseases such as cancer, diabetes, renal disease and arthritis. ${ }^{37,38}$ The elimination of NO by NO scavengers or the inhibition of its production by iNOS inactivator alleviates these illness conditions. Thus, the scavenging of NO or suppression of NO production by iNOS are clearly promising indices in the screening of new functional foods. ${ }^{39,40}$

The studied bioactive formulations exhibited antibacterial activity against all bacteria tested (Table 4 ). The $P$. ostreatoroseus basidioma ethanolic extract presented higher antibacterial activity than the correspondent mycelium extract against Staphylococcus aureus, Bacillus cereus, Pseudomonas aeruginosa, Escherichia coli, Salmonella typhimurium and Enterobacter cloacae. The basidioma-based formulation also presented an antibacterial activity similar to the commercial antibiotic 
Table 4 Antibacterial and antifungal activities of $P$. ostreatoroseus fruiting body- and mycelium-based formulations ${ }^{a}$

\begin{tabular}{|c|c|c|c|c|}
\hline \multirow[b]{2}{*}{ Bacteria } & \multirow{2}{*}{$\frac{\text { Fruiting body }}{\text { MIC/MBC }}$} & \multirow{2}{*}{$\frac{\text { Mycelium }}{\text { MIC/MBC }}$} & \multirow{2}{*}{$\frac{\text { Streptomycin }}{\mathrm{MIC} / \mathrm{MBC}}$} & \multirow{2}{*}{$\frac{\text { Ampicillin }}{\text { MIC/MBC }}$} \\
\hline & & & & \\
\hline Bacillus cereus & $0.15 / 0.30$ & $0.40 / 0.75$ & $0.05 / 0.10$ & $0.10 / 0.15$ \\
\hline Listeria monocytogenes & $0.60 / 1.20$ & $0.60 / 1.20$ & $0.15 / 0.30$ & $0.15 / 0.30$ \\
\hline Micrococcus flavus & $0.60 / 1.20$ & $0.45 / 0.60$ & $0.13 / 0.25$ & $0.10 / 0.15$ \\
\hline Pseudomonas aeruginosa & $0.30 / 1.20$ & $0.60 / 1.20$ & $0.05 / 0.10$ & $0.10 / 0.20$ \\
\hline \multirow[t]{2}{*}{ Enterobacter cloacae } & $0.30 / 0.60$ & $0.60 / 1.20$ & $0.05 / 0.10$ & $0.15 / 0.20$ \\
\hline & Fruiting body & Mycelium & Bifonazole & Ketoconazole \\
\hline Fungi & $\mathrm{MIC} / \mathrm{MFC}$ & MIC/MFC & $\mathrm{MIC} / \mathrm{MFC}$ & $\mathrm{MIC} / \mathrm{MFC}$ \\
\hline Aspergillus fumigatus & $0.60 / 2.40$ & $0.60 / 3.60$ & $0.15 / 0.20$ & $0.20 / 0.50$ \\
\hline Penicillium funiculosum & $0.30 / 0.60$ & $0.60 / 1.20$ & $0.20 / 0.25$ & $0.20 / 0.50$ \\
\hline Penicillium ochrochloron & $0.60 / 3.60$ & $0.30 / 0.60$ & $0.20 / 0.25$ & $2.50 / 3.50$ \\
\hline P. verrucosum & $0.60 / 3.60$ & $1.20 / 2.40$ & $0.10 / 0.20$ & $0.20 / 0.30$ \\
\hline
\end{tabular}

streptomycin (MIC $0.25 \mathrm{mg} \mathrm{mL}^{-1}$ ) against Staphylococcus aureus. Both studied formulations possessed the same activity against Listeria monocytogenes, and it was only in the case of Micrococcus flavus that the mycelium-based preparation presented higher antibacterial activity than the fruiting bodybased formulation. Alves et al. ${ }^{10}$ reported high antibacterial activity of an ether extract of Pleurotus pulmonarius against Staphylococcus aureus. Tambekar et al. ${ }^{41}$ reported the antimicrobial ability of ethanolic, methanolic and xylene extracts of P. pulmonarius against Escherichia coli and Pseudomonas aeruginosa. Sulphated polysaccharides from P. eryngii showed inhibition against Escherichia coli, Staphylococcus aureus and Listeria monocytogenes. ${ }^{42}$

Regarding antifungal activity (Table 4), the P. ostreatoroseus basidioma ethanolic extract presented higher activity than the correspondent mycelium-based preparation against Aspergillus versicolor, A. ochracues, A. niger, Trichoderma viride, Penicillium funiculosum and P. verrucosum. The studied basidioma ethanolic extract also presented similar antifungal activity to that of the commercial antibiotic bifonazole $\left(0.15 \mathrm{mg} \mathrm{mL}^{-1}\right)$ against Aspergillus ochracues and Trichoderma viride. Both bioactive formulations possessed the same activity against Aspergillus fumigatus. It was only in the case of Penicillium ochrochloron that the mycelium-based formulation presented higher antifungal activity than the fruiting body-based preparation. Hearst et $a l{ }^{43}$ found no antifungal activity in the aqueous extract of Pleurotus ostreatus against Aspergillus fumigatus, A. niger and Penicillium sp. Moreover, Wang et $a l .{ }^{44}$ reported the activity of an antifungal peptide isolated from Pleurotus eryngii fruiting bodies and Ngai et al. ${ }^{45}$ reported antifungal effects of a ribonuclease isolated from basidiomas of $P$. pulmonarius. In both cases, the inhibition of mycelium growth was against Fusarium oxysporum and Mycosphaerella arachidicola.

As the $P$. ostreatoroseus bioactive formulations displayed antioxidant, anti-inflammatory and antimicrobial activity, it was important to guarantee an absence of cytotoxicity against liver cells, which are considered the best in vitro model for studies of human cytotoxicity. The studied samples revealed no toxicity in liver primary culture PLP2, since the $\mathrm{GI}_{50}$ values obtained were higher than the highest concentration tested $\left(>400 \mu \mathrm{g} \mathrm{mL} \mathrm{m}^{-1}\right)$. The positive control ellipticine gave a $\mathrm{GI}_{50}=$ $2.29 \mu \mathrm{g} \mathrm{mL}^{-1}$ (Table 3).

Overall, and to the best of our knowledge, this is the first report of anti-inflammatory properties of $P$. ostreatoroseus fruiting body and mycelium extracts, and from the results obtained, a clear anti-inflammatory and antimicrobial potential of the tested samples can be inferred. Therefore, these formulations can be used to prepare dietary supplements for nutraceutical purposes.

\section{Conflict of interest}

The authors declare no competing financial interest.

\section{Acknowledgements}

The authors are grateful to the Foundation for Science and Technology (FTC, Portugal) for financial support to CIMO (Pest-OE/AGR/UI0690/2014), L. Barros's research contract ("Compromisso para a Ciência”) and R.C. Calhelha's grant 
(SFRH/BPD/68344/2010), and to the Serbian Ministry of Education, Science and Technological Development for the Grant No 173032. R.C.G. Correa thanks CAPES Foundation, Ministry of Education of Brazil (CAPES fellow, process number BEX 3974/14-6). R.M. Peralta and A. Bracht are Research Fellows of CNPq (Conselho Nacional de Desenvolvimento Científico e Tecnológico). The authors also thank A. Fernandes for all the support in some of the laboratory work.

\section{References}

1 R. P. Z. Furlani and H. T. Godoy, Rev. Inst. Adolfo Lutz, 2005, 64, 149-154.

2 I. C. F. R. Ferreira, S. A. Heleno, F. S. Reis, D. Stojkovicd, M. J. R. P. Queiroz, M. H. Vasconcelos and M. Sokovic, Phytochemistry, 2015, 114, 38-55.

3 S. A. Heleno, L. Barros, M. J. Sousa, A. Martins and I. C. F. R. Ferreira, Food Chem., 2010, 119, 1443-1450.

4 J. A. Vaz, L. Barros, A. Martins, J. S. Morais, M. H. Vasconcelos and I. C. F. R. Ferreira, LWT - Food Sci. Technol., 2011, 44, 343346.

5 L. Barros, C. Pereira and I. C. F. R. Ferreira, Food Anal. Methods, 2013, 6, 309-316.

6 L. Barros, P. Baptista, D. M. Correia, S. Casal, B. Oliveira and I. C. F. R. Ferreira, Food Chem., 2007, 105, 140145.

7 L. Barros, T. Cruz, P. Baptista, L. M. Estevinho and I. C. F. R. Ferreira, Food Chem. Toxicol., 2008, 46, 27422747.

8 M. Elmastas, O. Isildak, I. Turkekul and N. Temur, J. Food Compos. Anal., 2007, 20, 337-345.

9 I. C. F. R. Ferreira, L. Barros and R. M. V. Abreu, Curr. Med. Chem., 2009, 16, 1543-1560.

10 M. J. Alves, I. C. F. R. Ferreira, J. Dias, V. Teixeira, A. Martins and M. Pintado, Planta Med., 2012, 78, 17071718.

11 J. C. P. Cardoso, P. L. M. M. Demenjour and M. F. Paz, Evidência, 2013, 13, 31-40.

12 A. Fernandes, L. Barros, A. Martins, P. Herbert and I. C. F. R. Ferreira, Food Chem., 2015, 169, 396-400.

13 G. C. S. Bazanella, D. F. De Souza, R. Castoldi, R. F. Oliveira, A. Bracht and R. M. Peralta, Folia Microbiol., 2013, 58, 641-647.

14 C. Ramos, M. Sapata, A. Ferreira, L. Andrada and M. Candeias, Rev. Cien. Agr., 2011, 34, 57-64.

15 C. P. Pokhrel, N. Kalyan, U. Budathoki and R. K. P. Yadav, Int. J. Agric. Pol. Res., 2013, 1, 19-23.

16 R. Singer, Publications of the Mycology Institute of the University of Recife, 1961, 304, 3-26.

17 F. R. Rosado, C. Kemmelmeier and S. M. G. Da Costa, J. Basic Microbiol., 2002, 42, 37-44.

18 E. R. Carbonero, A. H. P. Gracher, F. R. Smiderle, F. R. Rosado, G. L. Sassaki, P. A. J. Gorin and M. Iacomini, Carbohydr. Polym., 2006, 66, 252-257.
19 E. R. Carbonero, A. H. P. Gracher, M. C. C. Rosa, G. Torri, G. L. Sassaki, P. A. J. Gorin and M. Iacomini, Phytochemistry, 2008, 69, 252-257.

20 A. H. P. Gracher, T. R. Cipriani, E. R. Carbonero, P. A. J. Gorin and M. Iacomini, Thromb. Res., 2010, 126, e180-e187.

21 J.-T. Lin, C.-W. Liu, H.-C. Chen, C.-C. Hu, L.-D. Juang, C.-C. Shiesh and D.-J. Yang, LWT - Food Sci. Technol., 2014, 55, 374-382.

22 M. L. L. Silveira, F. R. Smiderle, C. P. Moraes, D. G. Borato, C. H. Baggio, A. C. Ruthes, A. C. E. Wisbeck, G. L. Sassaki, T. R. Cipriani, S. A. Furlan and M. Iacomini, Carbohydr. Polym., 2014, 113, 588-596.

23 M. L. L. Silveira, F. R. Smiderle, F. Agostini, E. M. Pereira, M. Bonatti-Chavesa, E. Wisbeck, A. C. Ruthes, G. L. Sassaki, T. R. Cipriani, S. A. Furlan and M. Iacomini, Int. J. Biol. Macromol., 2015, 75, 90-96.

24 AOAC, Association of Official Analytical Chemists, Arlington VA, USA, 16th edn, 1995.

25 H. A. Vogel, Microbiol. Gen. Bull., 1956, 13, 578-584.

26 A. E. S. S. Carvajal, E. A. Koehnlein, A. A. Soares, G. J. Eler, A. T. A. Nakashima, A. Bracht and R. M. Peralta, LWT Food Sci. Technol., 2012, 46, 493-499.

27 F. S. Reis, L. Barros, A. Martins and I. C. F. R. Ferreira, Food Chem. Toxicol., 2012, 50, 191-197.

28 F. S. Reis, A. Martins, L. Barros and I. C. F. R. Ferreira, Food Chem. Toxicol., 2012, 50, 1201-1207.

29 A. Espinel-Ingroff, J. Clin. Microbiol., 2001, 39, 13601367.

30 CLSI, Approved standard, 8th ed. CLSI publication M07-A8, Clinical and Laboratory Standards Institute, Wayne, PA, 2009.

31 C. Booth, Fungal culture media, in Methods in microbiology, ed. J. R. Norris and D. W. Ribbons, Academic Press, London and New York, 1971, pp. 49-94.

32 R. M. V. Abreu, I. C. F. R. Ferreira, R. C. Calhelha, R. T. Lima, M. H. Vasconcelos, F. Adega, R. Chaves and M. J. R. P. Queiroz, Eur. J. Med. Chem., 2011, 46, 5800-5806.

33 S. S. Patil, S. A. Ahmed, S. M. Telang and M. M. V. Baig, Innov. Rom. Food Biotechnol., 2010, 7, 66-76.

34 S. Beluhan and A. Ranogajec, Food Chem., 2011, 124, 10761082.

35 S.-Y. Tsai, S.-J. Huang, S.-H. Lo, T.-P. Wu, P.-Y. Lian and J.-L. Mau, Food Chem., 2009, 113, 578-584.

36 C. Moro, I. Palacios, M. Lozano, M. D’Arrigo, E. Guillamón, A. Villares, J. A. Martínez and A. García-Lafuente, Food Chem., 2012, 130, 350-355.

37 J. F. Comar, A. B. Sá-Nakanishi, A. L. Oliveira, M. M. N. Wendt, C. A. Bersani-Amado, E. L. Ishii-Iwamoto, R. M. Peralta and A. Bracht, Free Radicals Biol. Med., 2013, 58, 144-153.

38 M. N. N. Wendt, A. B. Sá-Nakanishi, C. V. C. Ghizoni, C. A. Bersani-Amado, R. M. Peralta, A. Bracht and J. F. Comar, Exp. Mol. Pathol., 2015, 98, 549-557.

39 P. J. Tsai, T.-H. Tsai, C.-H. Yu and S.-C. Ho, Food Chem., 2007, 103, 181-187. 
40 M. J. Rebelo, C. Sousa, P. Valentão, R. Rego and P. B. Andrade, Food Chem., 2014, 163, 16-22.

41 D. H. Tambekar, T. P. Sonar, M. V. Khodke and B. S. Khante, Int. J. Pharm., 2006, 2, 584-587.

42 S. Li and N. P. Shah, Food Chem., 2014, 165, 262-270.
43 R. Hearst, D. Nelson, G. McCollum, B. C. Millar, Y. Maeda, E. C. Goldsmith, P. J. Rooney, A. Loughrey, J. R. Rao and J. E. Moore, Comp. Ther. Clin. Pract., 2009, 15, 5-7.

$44 \mathrm{H}$. Wang and T. B. Ng, Peptides, 2004, 25, 1-5. 45 P. H. K. Ngai and T. B. Ng, Peptides, 2004, 25, 11-17. 